\title{
The growing competition in Brazilian science: rites of passage, stress and burnout
}

L. de Meis ${ }^{1}$, A. Velloso ${ }^{1}$,

D. Lannes ${ }^{1}$, M.S. Carmo ${ }^{1}$ and C. de Meis $^{2}$
1Departamento de Bioquímica Médica, Instituto de Ciências Biomédicas, Centro de Ciências da Saúde and ${ }^{2}$ Instituto de Psiquiatria, Universidade Federal do Rio de Janeiro, Rio de Janeiro, RJ, Brasil

\section{Correspondence}

L. de Meis

Departamento de Bioquímica Médica Instituto de Ciências Biomédicas CCS, UFRJ

Rio de Janeiro, RJ

Brasil

Fax: +55-21-2270-8647

E-mail: demeis@biqmed.ufrj.br

Research supported by $\mathrm{CNPq}$ and FAPERJ.

$\ldots \ldots \ldots \ldots \ldots \ldots$

Received August 4, 2003

Accepted August 5, 2003

\begin{abstract}
Brazil's scientific community is under pressure. Each year there is an increase in its contribution to international science and in the number of students who are trained to do research and teach at an advanced level. Most of these activities are carried out in state and federal universities, but with government funding that has decreased by more than 70\% since 1996. Interviews with graduate students, post-doctoral fellows and professors in one university department with a strong research tradition illustrate the level of stress engendered by the conflict between increasing competition and diminishing resources, and serve to underscore the negative effects on creativity and on the tendency to choose science as a career.
\end{abstract}

Key words - Science funding

- Public and private

universities

- Mental suffering

- Publish or perish

- Academic pressure

- MSc and PhD students

\section{Introduction}

The number of Brazilian authors and the number of Brazilian publications in the international scientific literature have grown substantially during the last decade. Contrasting with this growth, the resources allocated by the Brazilian government to science and technology in the 1996-2002 period decreased steadily (Figure 1). This remarkable discrepancy led us to study the effect of shrinking funds on scientists' everyday lives. A brief account of our findings has recently been published (1). The conclusion was that the shortage of funds promotes competition, job stress, burnout and mental suffering. In order to survive professionally, scientists need to publish at increasing rates and in journals with ever greater impact, generating a fret so well characterized recently by Lawrence (2).
Here we describe briefly the distribution of science in Brazil, and analyze 25 open interviews and 124 semi-structured interviews carried out among graduate students and professors of a biochemistry department of the Federal University of Rio de Janeiro that is considered highly qualified by Brazilian funding agencies.

\section{Brazilian science}

Unlike most of the developed countries, Brazil's population of young people (18 to 30 years old) has increased during the past two decades (Figure 2). Student enrollment in both private and government (state and federal) universities has also grown, as shown for the years 1995-2000 in Figure 3C. Education at government universities is free. The number of professors employed by private 
universities has increased, but this is not the case in government universities (Figure 3B). In 2001 there were 1,208 private and 183 government institutions (Figure 3A). The enrollment of students in the various fields of knowledge in the two types of universities is different; examples are shown in Table 1. While a majority of undergraduate students are enrolled in private universities (Table 1), most of the courses that train MSc and $\mathrm{PhD}$
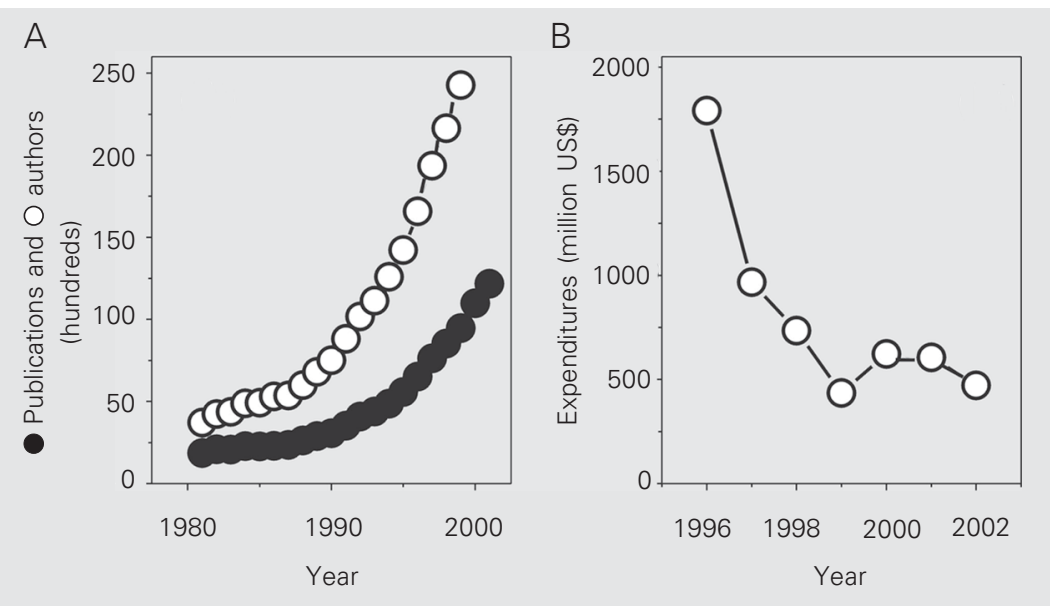

Figure 1. Scientific publications, authors, and expenditures in science and technology. A, Brazilian authors appearing in publications indexed by the Institute for Scientific Information (ISI; open circles); number of scientific publications (articles, reviews and letters) originating in Brazil and published in journals indexed by ISI (filled circles). B, Total federal expenditures on science and technology. Values in Brazilian currency (reais) were converted to US dollars using the average annual exchange rate. Source: "SIAFI/STM Elaboração: Consultoria de orçamento/CD e PRODASEN".

Figure 2. Young population. Number of 18- to 30 -year-olds in Brazil, USA, UK, France and Germany. Source: United Nations Population Division, World population prospect, Population database.

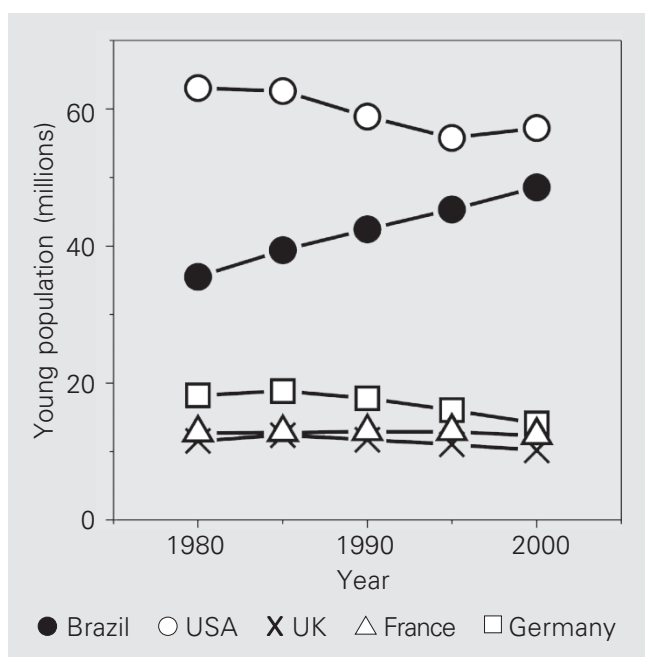

students are found in government universities (Figure 4 and Table 2). The graduate courses are evaluated regularly and ranked from 1 (lowest) to 7 (highest) by CAPES (Coordenação e Aperfeiçoamento de Pessoal de Nível Superior), a Brazilian agency of the Ministry of Education (Figure 4). Evaluation includes analysis of the curriculum vitae of the teaching staff, the number of years students take to defend their theses, and whether or not the thesis work leads to a scientific publication. Fellowships are granted to the courses rated 3 and above, to be distributed among their students.

From 1997 to 2000, Brazilian scientists published 34,274 papers in journals indexed by the Institute for Scientific Information (ISI; Figure 1A) and of these, 91.3\% were published from government institutions that have graduate courses. Science and training of new scientists are concentrated in a few government universities: $78.5 \%$ of the graduate courses rated 6 and 7 are located in 12 government universities, and the investigators in these institutions published $71.2 \%$ of the articles from Brazil that appeared in journals indexed by ISI between 1997 and 2000 (Table 3). Among these 12 universities, three of them, the University of São Paulo (USP), the Federal University of Rio de Janeiro (UFRJ) and the University of Campinas (UNICAMP), house $51.1 \%$ of the level 6-7 graduate courses and published $42.9 \%$ of the Brazilian articles indexed by ISI between 1997 and 2000 (Table 3). From this information, it can be gathered that Brazilian science is concentrated in a very few institutions and, since these centers are mainly governmental, science is basically supported by government funds.

\section{The competition}

The number of degrees granted every year has increased steadily during the past decade. The number of MSc and PhD students graduated in 1990 was 5,579 and 1,410, 


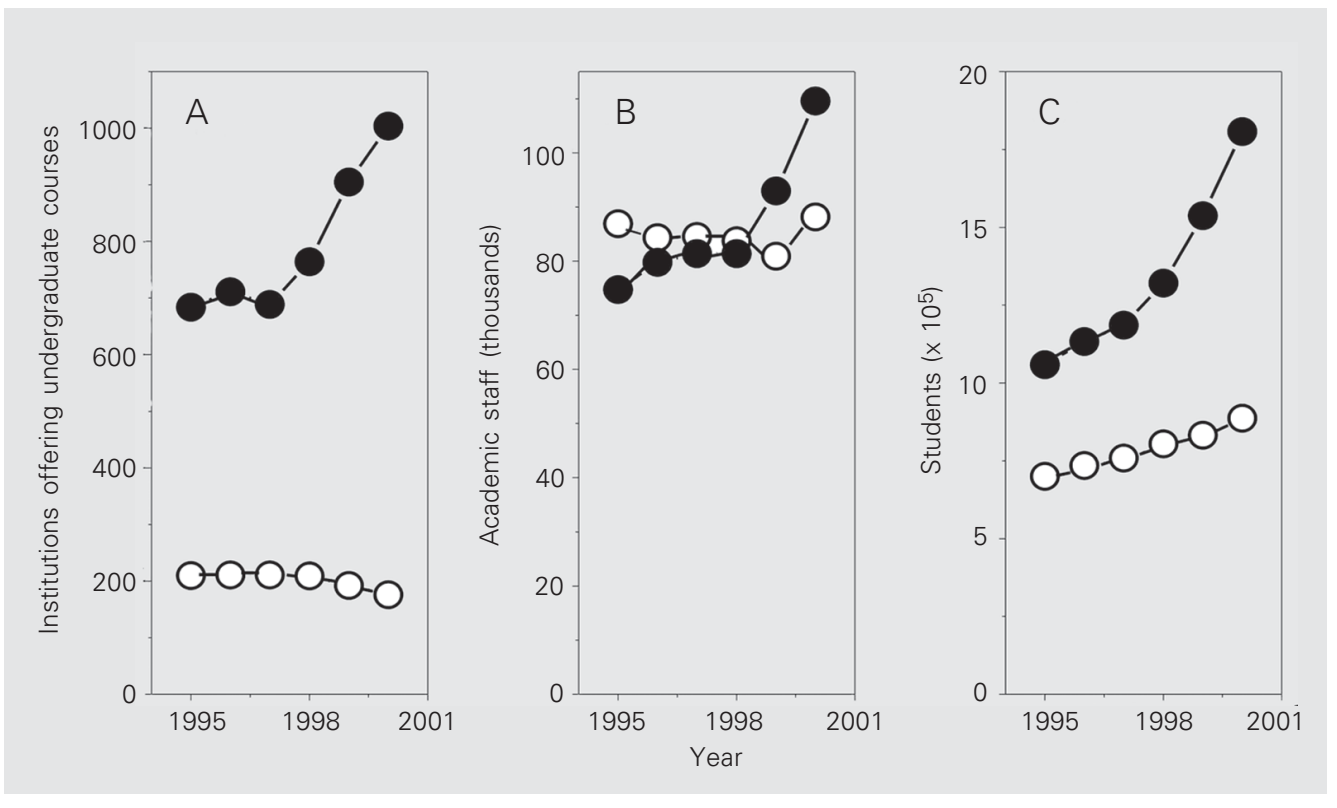

Figure 3. Number of institutions offering undergraduate courses (A), Academic staff (B) and Student enrollment (C) in government (open circles) and private Brazilian institutions (filled circles). In 2001 there were 939,225 students enrolled in federal and state universities and 2,091,521 students in private universities. Source: Instituto Nacional de Estudos e Pesquisas Educacionais Anísio Teixeira (INEP) - 2001 Census.

respectively, and this increased to 18,374 and 5,344 in 2000. Most of the new professionals entering the work market have been absorbed by private universities, where research is scant. Only a few research positions are available in industry and in government universities each year. In 2001 the Conselho Nacional de Desenvolvimento Científico e Tecnológico (CNPq), a Brazilian agency of the Ministry of Science and Technology, created a new fellowship intended to allow 100 young investigators with a $\mathrm{PhD}$ degree and a good scientific background to become affiliated with active research centers. The program was called "PROFIX"; 1,154 candidates competed for the 100 positions available. In the same year, $\mathrm{CNPq}$ offered to the scientific community as a whole research grants varying from US $\$ 2,000$ up to US $\$ 43,600$ for a two-year period. For the section that included biochemistry, biophysics, physiology, pharmacology and neurosciences there were 437 applications. Of this number, 267 were approved on scientific merit but the resources available allowed the funding of only 20 applications. Both for the PROFIX program and for the research grants the main selec-
Table 1. Undergraduate enrollment and fields of knowledge taught in government and private universities.

\begin{tabular}{lccc}
\hline Fields of knowledge & $\begin{array}{c}\text { Number of students } \\
\text { enrolled in both } \\
\text { government and } \\
\text { private universities }\end{array}$ & $\begin{array}{c}\text { Fraction of } \\
\text { students enrolled } \\
\text { in government } \\
\text { universities (\%) }\end{array}$ & $\begin{array}{c}\text { Fraction of } \\
\text { students enrolled } \\
\text { in private } \\
\text { universities (\%) }\end{array}$ \\
\hline Law & 414,519 & 13.9 & 86.9 \\
Business \& Administration & 356,156 & 12.8 & 87.2 \\
Medicine & 57,930 & 53.4 & 46.6 \\
Mathematics & 19,649 & 55.8 & 44.2 \\
Chemistry & 18,224 & 61.6 & 38.4 \\
Earth sciences & 22,302 & 81.8 & 18.2 \\
Physics & 8,639 & 95.3 & 4.7 \\
All fields & $3,030,754$ & 31.0 & 69.0 \\
\hline
\end{tabular}

Source: Instituto Nacional de Estudos e Pesquisas Educacionais Anísio Teixeira (INEP) - Census, 2001.

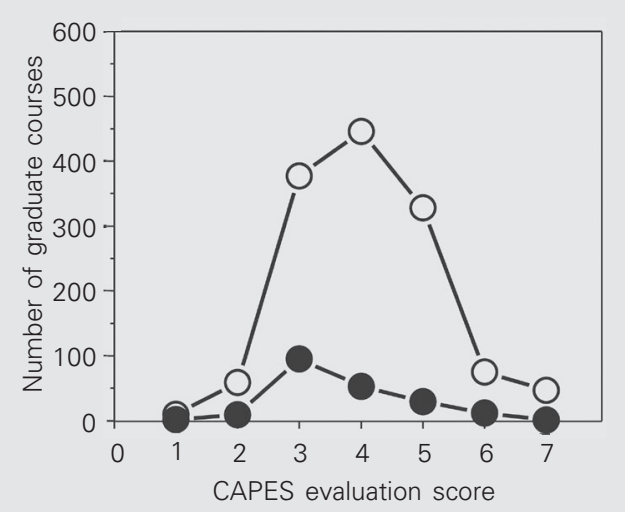

Figure 4. Evaluation of graduate courses in Brazil in 2001 in government (open circles) and private universities (filled circles). A total of 1,544 graduate courses were rated from level 1 to 7 by CAPES (Coordenação e Aperfeiçoamento de Pessoal de Nível Superior), including 1,343 from government and 201 from private universities. Source: CAPES. 
Table 2. Graduate courses.

\begin{tabular}{lcc}
\hline Fields of knowledge & $\begin{array}{c}\text { Government } \\
\text { universities }\end{array}$ & $\begin{array}{c}\text { Private } \\
\text { universities }\end{array}$ \\
\hline Life sciences & 569 & 53 \\
Exact sciences & 285 & 23 \\
Earth sciences & 168 & 5 \\
Environment & 15 & 0 \\
Social sciences & 306 & 120 \\
Total & 1,343 & 201 \\
\hline
\end{tabular}

Source: Instituto Nacional de Estudos e Pesquisas Educacionais Anísio Teixeira (INEP) - Census, 2001.

Table 3. Publications (1997 to 2000) and outstanding graduate courses.

\begin{tabular}{lcc}
\hline Universities* & Publications** $^{*}$ & $\begin{array}{c}\text { Courses level } \\
6 \text { and } 7^{* * *}\end{array}$ \\
\hline USP & 7,999 & 36 \\
UFRJ & 3,301 & 19 \\
UNICAMP & 3,413 & 14 \\
UFMG & 1,915 & 9 \\
UFRGS & 1,693 & 7 \\
UNB & 723 & 6 \\
UFSC & 901 & 4 \\
UFPE & 734 & 3 \\
UNIFESP & 1,150 & 3 \\
UFSCAR & 1,021 & 3 \\
UFPR & 784 & 1 \\
UFF & 755 & 1 \\
Subtotal & $24,389(71.2 \%)$ & $106(78.5 \%)$ \\
Total for Brazil & $34,274(100 \%)$ & $135(100 \%)$
\end{tabular}

*USP $=$ University of São Paulo, UFRJ = Federal University of Rio de Janeiro, UNICAMP = University of Campinas, UFMG = Federal University of Minas Gerais, UFRGS = Federal University of Rio Grande do Sul, UNB = University of Brasília, UFSC = Federal University of Santa Catarina, UFPE = Federal University of Pernambuco, UNIFESP = Federal University of São Paulo, UFSCAR = Federal University of São Carlos, UFPR $=$ Federal University of Paraná, and UFF = Federal Fluminense University. ${ }^{*}$ Publications: includes articles, letters and reviews originating in Brazil and published in journals indexed by the Institute for Scientific Information (ISI). ${ }^{* *}$ Classified by CAPES (Coordenação e Aperfeiçoamento de Pessoal de Nível Superior) on a scale of 1 (low) to 7 (high). tion criterion was the scientific background of the candidates, as evaluated by the number of scientific publications and the impact of the journals where the papers were published.

\section{Perception of the problem by the academic staff}

It was not surprising therefore that the narratives of graduate students, postdoctoral fellows and teaching staff when interviewed revolved around publications and journal impact, increasing competition, disappointment and uncertainty about their careers. A common feature of the respondents in the interviews was a high degree of involvement with their work. Typical statements of graduate students were:

1. "You can fly, you can imagine something out of the blue, something that Nature itself thought about... and you can discover it!";

2. "A fellow that earns a meager salary like that one, well, he must really like what he does... otherwise, he doesn't live";

3. "Why do you think there are so many couples in science... they literally live locked in the laboratory. They forget that there is a whole world outside, and the only partner they can meet is in the laboratory".

Concerning this last statement we found out that 26 of the 39 established investigators of the department were married among themselves (13 married couples - 66.7\%), 2 were currently unmarried but had been married to fellow scientists (5.1\%), 3 were single (7.7\%), and only 8 were married to partners who had jobs unrelated to academia $(20.5 \%)$.

The publication of articles and the impact of the journals where papers are published were the main concern of both graduate students and investigators. Typical narratives were:

4. "He is a very helpful fellow... he has great ideas and I always learn a lot from him, but this is not enough... In this place 
you are only acknowledged when you have publications... the rest doesn't matter";

5. "He [the thesis advisor] doesn't care about my thesis. He believes that a thesis is the consequence of good work and good work means papers published in good journals";

6. "You feel a constant pressure to publish...";

7. "What we hear is that you are worth what you publish... the currency in this arena is publications";

8. "My boss has a lot of publications... but when you go and look for what he discovered... you can define it in three sentences: he discovered this, this and that. The rest was to train students and get grants".

When the respondents referred to their colleagues' work, they usually referred to the number of publications and the journals, not knowing clearly what it was that had been discovered. Scientific reputation therefore seems to be built on the basis of scientometrics, assuming that the impact of the journals reflects the novelty and importance of the discoveries:

9. "They evaluate people by the number of publications... and then they classify them by the impact of the journals: high-impact and low-impact scientists...".

The submission of a paper evokes strong emotions, and frequently the respondent is concerned with what his peers will think of him when they learn about the acceptance or rejection:

10. "My major concern was to publish, to be recognized... it was a kind of self-affirmation, so I could tell them, 'Look, I am good!'”;

11. "When the journal does not accept, you feel as if it is not only your paper, but you yourself that is rejected... They look at you as if you do not deserve to be there... it is a very bad feeling!";

12. "It is a great feeling to have a paper accepted, mainly when you know that so many people have their papers rejected...".

The difficulty in obtaining research sup- port, in a country where funding is mainly governmental, generates anxiety and a strong feeling of insecurity both in individuals that have recently been awarded a $\mathrm{PhD}$ and in established investigators:

13. "When I got my PhD degree I thought: 'Now what am I going to do? It isn't possible that I have worked so hard not to be absorbed by the system"';

14. "You fulfill all requirements, you work very hard... but you are not sure if at the end you will get a job...";

15. "If you stop publishing, you lose your grant... You are ejected from the system, it doesn't matter what you did in the past - it only matters what you have done in the last 2 to 3 years";

16. "At times I feel so anxious... you must complete your thesis in a short period of time, you have an advisor who guides you but at the same time continuously demands results, because we live in a system that constantly demands more and more from the advisor, and so it goes on down the line, in a cascade...";

17. "I began to feel paranoid. I did not want to work any longer, I wanted to quit. Everything was dark... when I arrived at the lab I did not feel well, I felt sick...".

The result of grant evaluation is always associated with strong feelings, regardless of whether or not it is approved:

18. "I hate all of this, including the people who work here... I want to retire, to go away... I feel a knot in my stomach every time the car gets near the university... I hate those people that got the money... they are no better than I, nor do they publish more than I do, and I have to use my salary to keep the laboratory going";

19. "I knew they would publish the result of the evaluation that night, so I went home and after dinner, I went to the computer quietly. ...my heart was pounding inside me, I could feel it thump, thump, thump while I looked up the list and then... My name was there, I was awarded! ... and then I started 
crying, and I cried and cried... I went and hugged my wife, crying... and all of that just for a lousy grant of less than 8,000 dollars per year".

In a highly competitive atmosphere, Brazilian science might be improving, but what is the impact of this situation on the individual, particularly on students who have worked very hard to get their PhDs and need to find their place in the scientific community?

\section{Rites of passage}

There are moments, defined as rites of passage, which demarcate the transition in the subject's life from one clearly defined social position to another, still unfamiliar to him. According to Van Gennep (3), the rites are divided into three stages: the "death" of the old social role, the "margin" or "transition", and the "rebirth" into a new role in society. The margin is a time when the subject lives in a situation between death and rebirth. In this stage social rules are suspended because the subject no longer belongs to the "Old World", nor has the person entered the "New World" where he or she will exist from now on. At this moment the subject is in nowhereland. According to Turner (4), "the attributes of liminality or laminar personae are necessarily ambiguous, since the condition and these persons elude or slip through the network of classifications that normally locate states and positions in cultural space. Laminar entities are neither here nor there; they are between the positions assigned and arrayed by law, custom and conventions".

The transition period in the ritual of passage and the liminality are conditions where anxiety, doubt about one's capacity to cope with the situation, stress and mental suffering are highlighted.

In universities where there is no research, the thesis defense is a rite of passage, legitimization as part of the teaching staff coming mainly from the academic title of $\mathrm{PhD}$. In contrast with this situation, in the biochemistry department studied, the ritual of passage is the publication of a paper in a journal indexed by ISI, and the thesis is simply "the consequence of good work and good work means papers published in good journals" (see statements 5, 10). In the department studied, where the graduate course is ranked 7 by CAPES, legitimization never really arrives. The trajectory of the scientist becomes an increasingly difficult battle for grants, where the individual may lose support at any time (see for instance statements 13 to 16). The idea of a continuous and stable career is blurred, and the individual must continually prove his or her capacity, being always in a transition state or liminality with the chances of being eliminated from the system increasing every year (Figure 1B and statements 11, 14 to 16 ).

\section{Job burnout}

The extended transition state may contribute to a condition of emotional and mental exhaustion at work, defined as burnout, a phenomenon that has a significant impact on modern culture $(5,6)$. The interviews suggested that the situation characterized in Figure $1 \mathrm{~B}$ promotes this condition among the population studied. Those most prone to develop burnout are the dedicated and committed workers (see statements 1 to 3 ). Burnout seems to be caused by frustrated hopes and expectations, a feeling of inadequate control over one's work and a feeling of losing the meaning of life. These elements are present in statements 11 and 13 to 19 . The key symptoms of burnout are emotional and mental exhaustion, feelings of cynicism with negative and detached response to various aspects of the job and a sense of ineffectiveness and lack of accomplishment. These symptoms were described in statements 4 , 11, and 13 to 19. The likelihood of burnout increases when there is significant and pro- 
longed occupational stress, including work overload and inadequate resources to meet the stress. These situations are characterized by Figure 1 and statements 6, 15, 17 and 18 . The burnout syndrome leads to a progressive loss of idealism and has been associated with impaired job performance and poor health, including headaches, hypertension, anxiety and depression - see statements 11, 14 and 17 to 19. Different authors report that burnout may lead to alcohol and drug abuse and deterioration of relationships with family and friends.

\section{Conclusion}

The number of Brazilians attending universities is increasing steadily, thereby increasing the chance of identifying and nurturing new scientific talents (Figures 2 and 3 ). This reservoir of young talent is probably contributing to the increase in the number of Brazilian authors appearing in international scientific journals (Figure 1A). However, the discrepancy between the scarcity of funds and the need for publications is leading to the "publish or perish" condition experi- enced in the USA during the seventies, with the difference that in the USA this occurred at a time when science was well established, while in Brazil it is taking place at an early stage of its scientific development. This pressure to publish is leading to an exaggerated degree of competitiveness, propagating a cultural distortion where scientometrics prevails over knowledge and where mental suffering is making up for the lack of funds, i.e., is directly proportional to the lack of funds. One of the possible future scenarios is that a significant proportion of Brazilian scientists will leave academia and new talents will be discouraged from choosing a scientific career due to its bleak perspective. The combination of these two factors may lead to a decline of Brazilian science. Thus, if this pattern is not reversed in the near future, Brazilian science may go from growth to decay without ever realizing its full potential.

\section{Acknowledgments}

We thank Dr. V. Rumjanek and Dr. M. Sorenson for useful discussions.

\section{References}

1. de Meis L, Carmo MS \& de Meis C (2003). Impact factors: just part of a research treadmill. Nature, 424: 723 .

2. Lawrence PA (2003). The politics of publication. Nature, 422: 259261.

3. Van Gennep A (1960). The Rites of Passage. Routledge \& Kegan Paul, London, England.

4. Turner V (1969). The Ritual Process: Structure and Antistructure.
Aldine Publishing Company, Chicago, IL, USA.

5. Maslach C, Schaufeli WB \& Leiter MP (2001). Job burnout. Annual Review of Psychology, 52: 397-442.

6. Iacovides A, Fountoulakis KN, Kaprinis St \& Kaprinis G (2002). The relationship between job stress, burnout and clinical depression. Journal of Affective Disorders, 75: 209-221. 